Article

\title{
Epigallocatechin Gallate-Gold Nanoparticles Exhibit Superior Antitumor Activity Compared to Conventional Gold Nanoparticles: Potential Synergistic Interactions
}

\author{
Suhash Reddy Chavva ${ }^{1}$, Sachin Kumar Deshmukh ${ }^{1}$, Rajashekhar Kanchanapally ${ }^{1}$, \\ Nikhil Tyagi ${ }^{1}$, Jason William Coym ${ }^{2}$, Ajay Pratap Singh ${ }^{1,3, *}$ and Seema Singh ${ }^{1,3, *}$ \\ 1 Department of Oncologic Sciences, Mitchell Cancer Institute, University of South Alabama, \\ Mobile, AL 36604, USA; srchavva@health.southalabama.edu (S.R.C.); \\ skdeshmukh@health.southalabama.edu (S.K.D.); rkanchanapally@health.southalabama.edu (R.K.); \\ nikhiltyagi22@gmail.com (N.T.) \\ 2 Department of Chemistry, University of South Alabama, Mobile, AL 36688, USA; \\ jwcoym@southalabama.edu \\ 3 Department of Biochemistry and Molecular Biology, College of Medicine, University of South Alabama, \\ Mobile, AL 36688, USA \\ * Correspondence: asingh@health.southalabama.edu (A.P.S.); seemasingh@health.southalabama.edu (S.S.); \\ Tel.: +1-251-445-9843 (A.P.S.); +1-251-445-9844 (S.S.)
}

Received: 14 February 2019; Accepted: 2 March 2019; Published: 8 March 2019

check for updates

\begin{abstract}
Epigallocatechin gallate (EGCG) possesses significant antitumor activity and binds to laminin receptors, overexpressed on cancer cells, with high affinity. Gold nanoparticles (GNPs) serve as excellent drug carriers and protect the conjugated drug from enzymatic metabolization. Citrate-gold nanoparticles (C-GNPs) and EGCG-gold nanoparticles (E-GNPs) were synthesized by reduction methods and characterized with UV-visible spectroscopy, transmission electron microscopy (TEM), and dynamic light scattering (DLS). Cytotoxicity of citrate, EGCG, C-GNPs, and E-GNPs was evaluated by the water-soluble tetrazolium salt (WST-1) assay. Nanoparticle cellular uptake studies were performed by TEM and atomic absorption spectroscopy (AAS). Dialysis method was employed to assess drug release. Cell viability studies showed greater growth inhibition by E-GNPs compared to EGCG or C-GNPs. Cellular uptake studies revealed that, unlike C-GNPs, E-GNPs were taken up more efficiently by cancerous cells than noncancerous cells. We found that E-GNP nanoformulation releases EGCG in a sustained fashion. Furthermore, data showed that E-GNPs induced more apoptosis in cancer cells compared to EGCG and C-GNPs. From the mechanistic standpoint, we observed that E-GNPs inhibited the nuclear translocation and transcriptional activity of nuclear factor-kappaB (NF- $\mathrm{B}$ ) with greater potency than EGCG, whereas C-GNPs were only minimally effective. Altogether, our data suggest that E-GNPs can serve as potent tumor-selective chemotoxic agents.
\end{abstract}

Keywords: EGCG; gold nanoparticle; synergism; cancer therapy; apoptosis; NF-kB

\section{Introduction}

Cancer is a major public health problem worldwide [1]. It is projected that in the United States nearly 1,735,350 new cancer cases will be diagnosed and 609,640 people will die from this disease in 2018 [1]. Clearly, there is a need to tackle cancer on multiple fronts, including the development of effective prevention and therapeutic strategies. One major issue with existing cancer chemotherapeutics is their high toxicity to healthy tissues at optimally effective doses, which limits their therapeutic potential $[2,3]$. As an alternative, several dietary phytochemicals have emerged as 
molecules of choice due to their high antitumor properties and negligible toxicities [4]. However, such agents suffer from poor solubility, stability, and cellular uptake; development of approaches is required to overcome these critical barriers [5].

Epigallocatechin gallate (EGCG) is one of the most abundant and active polyphenols found in green tea. It has a wide spectrum of therapeutic properties, including anti-inflammatory, anti-obesity, antidiabetic, and antitumor effects [6-8]. It has been documented that EGCG has anticancer activity in many cancers, including melanoma, prostate cancer, breast cancer, and pancreatic cancer [8-11]. EGCG has also been shown to bind to laminin receptors, which are overexpressed in many types of cancer, with high affinity and specificity [12-15]. Despite its ability to act as an excellent chemopreventive, therapeutic, and targeting agent, EGCG has limitations related to stability, bioavailability, and metabolic transformations under physiological conditions [16-18]. Nanoparticles (structures less than $100 \mathrm{~nm}$ in size, in at least one dimension) serve as excellent carriers of drugs due to their small size, which provides a large functional adsorbent surface per unit mass. Specially, gold nanoparticles (GNPs) are considered a better option than other nanoparticle formulations because of their biocompatibility, ease of synthesis, chemical stability, unique optical properties, and ease of surface modification as they can bind to molecules containing $-\mathrm{SH}$ and $-\mathrm{NH}_{2}$ [19]. Their biomedical applications in chemical sensing, biological imaging, and drug delivery have been demonstrated [20-22]. Importantly, GNPs are also shown to confer anticancer activity by directly acting on the tumor cells and/or by impacting the tumor microenvironment [23-27]. Furthermore, it has been demonstrated that conjugation of ligands to GNPs by nonspecific interactions increases their stability, by protecting them from enzymatic degradation [28].

In the present study, we synthesized GNPs using conventional method (citrate-GNPs/C-GNPs) and by using EGCG as a reducing agent (E-GNPs) and compared their antitumor efficacies in a variety of established cancer cell lines. Our data demonstrate that E-GNPs have greater cancer growth inhibitory potential, compared to free EGCG or C-GNPs. This appears to be associated with their greater uptake by the cancer cells and their increased potency for inhibition of the nuclear translocation of nuclear factor-kappaB (NF-kB). Together, these findings are indicative that E-GNPs have superior anticancer activity over C-GNPs, due to synergistic interactions between EGCG and GNPs.

\section{Materials and Methods}

Reagents: The following reagents were obtained from different vendors: Dulbecco's modified Eagle's medium (DMEM) and fetal bovine serum (FBS) from Atlanta Biologicals (Lawrenceville, GA, USA); penicillin (100 units $/ \mathrm{mL})$, streptomycin $(100 \mu \mathrm{g} / \mathrm{mL})$, and trypsin-EDTA from Invitrogen, (Carlsbad, CA, USA); cell proliferation reagent, water-soluble tetrazolium salt (WST-1) and TRIzol from Roche Diagnostics (Mannheim, Germany) and Life Technologies (Carlsbad, CA, USA), respectively. PE Annexin V apoptosis detection kit was from BD Bioscience (San Diego, CA, USA); gold (III) chloride trihydrate $\left(\mathrm{HAuCl}_{4} \cdot 3 \mathrm{H}_{2} \mathrm{O}\right)$, trisodium citrate (TSC), and citrate assay kit were from Sigma-Aldrich (St. Louis, MO, USA); nuclear extract kit was from Active Motif (Carlsbad, CA, USA); epigallocatechin gallate (EGCG) was from Medchemexpress LLC (Monmouth Junction, NJ, USA); anti-cleaved caspase 7, -cleaved caspase 3 (rabbit polyclonal), anti-BCL2, -BCL-xL, -Bax, -NF-kB/p65 (rabbit monoclonal) were from Cell Signaling Technology (Danvers, MA, USA); anti-laminin receptor antibody (MLuC5, mouse monoclonal) was from Invitrogen (Carlsbad, CA, USA); anti-rabbit and anti-mouse horseradish peroxidase (HRP)-conjugated secondary antibodies were from Santa Cruz Biotechnology (Santa Cruz, CA, USA); $\beta$-actin (mouse monoclonal) antibody was from Sigma-Aldrich; ECL plus detection kit was from Thermo Scientific (Logan, UT, USA); pGL4.32 [luc2P/NF-B-RE/Hygro] and pRL-TK plasmids were from Promega (Madison, WI, USA); TRIzol reagent and reverse-transcribed with high capacity cDNA reverse transcription kit were from Invitrogen and Applied Biosystems (Carlsbad, CA, USA); SYBR green master mix was from Applied Biosystems (Carlsbad, CA, USA); tris-buffered saline (TBS) and Tween 20 were from Boston Bioproducts (Ashland, MA, USA). 
Cell culture: The human normal and cancer cell lines (MCF-10A, hTERT-HPNE [HPNE], RWPE1, MDA-MB-231, MIA PaCa, and PC3) were purchased from ATCC (Manassas, VA, USA). The normal immortalized keratinocytes (HaCaT) were obtained from the German Cancer Research Center (Heidelberg, Germany). A375SM cell line was obtained from Dr Isaiah J Fidler (University of Texas MD Anderson Cancer Center, Houston, TX, USA). All the cell lines were maintained in DMEM (GE Healthcare Life Sciences) supplemented with 10\% fetal bovine serum (FBS, Atlanta Biologicals), penicillin (100 units $/ \mathrm{mL})$, and streptomycin $(100 \mu \mathrm{g} / \mathrm{mL})$ (Invitrogen) in a humidified atmosphere of $5 \% \mathrm{CO}_{2}$ at $37^{\circ} \mathrm{C}$. Cells were intermittently tested for mycoplasma contamination at our institutional flow cytometry core facility and determined to be free from infection.

Citrate-gold nanoparticle synthesis and characterization: Citrate-gold nanoparticles (C-GNPs) were synthesized by reducing $\mathrm{HAuCl}_{4} \cdot 3 \mathrm{H}_{2} \mathrm{O}$ with trisodium citrate (TSC) as reported earlier, with some modifications [21]. In brief, $10 \mathrm{mM}$ solution of $\mathrm{HAuCl}_{4} \cdot 3 \mathrm{H}_{2} \mathrm{O}$ and $1.0 \mathrm{wt} \%$ of TSC were prepared using deionized (DI) water. An initial volume of $1.25 \mathrm{~mL}$ of $10 \mathrm{mM} \mathrm{HAuCl}{ }_{4} \cdot 3 \mathrm{H}_{2} \mathrm{O}$ solution was diluted to $100 \mathrm{~mL}$ with DI water, and the obtained solution was brought to boiling temperature in a two-neck round-bottom flask fitted with a reflux condenser while being stirred. TSC solution $(0.85 \mathrm{~mL}, 1.0 \mathrm{wt} \%)$ was added to the boiling solution. Boiling and stirring were continued for another $30 \mathrm{~min}$ after the final color change to wine red, indicating the formation of C-GNPs. After cooling to room temperature, the gold nanoparticle solution was centrifuged at $5000 \mathrm{rpm}$ for $2 \mathrm{~h}$. After centrifugation, the supernatant was discarded, and the centrifugate was resuspended in deionized water. The gold nanoparticles were characterized by UV-visible absorption spectroscopy (Ocean Optics FLAME-CHEM-UV-VIS, Largo, FL, USA), transmission electron microscopy (TEM, JEOL-1011, Tokyo, Japan), and dynamic light scattering (DLS) (DelsaMax Pro light scattering analyzer, Backman Coulter Inc., Atlanta, GA, USA).

EGCG-gold nanoparticle synthesis and characterization: EGCG-gold nanoparticles (E-GNPs) were prepared by the reduction of $\mathrm{HAuCl}_{4} \cdot 3 \mathrm{H}_{2} \mathrm{O}$ using EGCG as the reducing agent. For this, $1.5 \mathrm{mM}$ EGCG solution was prepared by dissolving a sufficient amount of EGCG in $25 \mathrm{~mL}$ deionized water under magnetic stirring. To this solution, $25 \mathrm{~mL}$ of $2 \mathrm{mM} \mathrm{HAuCl} \mathrm{H}_{4} \cdot 3 \mathrm{H}_{2} \mathrm{O}$ was added dropwise at room temperature under continuous magnetic stirring. The reaction mixture immediately turned the color of red wine, indicating the formation of E-GNPs. Stirring was continued for another five minutes, and particles were washed twice with DI water by centrifugation at $5000 \mathrm{rpm}$ for $2 \mathrm{~h}$. Thus obtained particles were resuspended in DI water to the desired concentration and stored at $4{ }^{\circ} \mathrm{C}$ for future use. Nanoparticles were characterized by UV-visible absorption spectroscopy (Ocean Optics FLAME-CHEM-UV-VIS), TEM (JEOL-1011), and DLS (Backman Coulter Inc.).

Estimation of citrate loading: After synthesis of C-GNPs by citrate reduction method, the nanoparticles were centrifuged at 10,000 rpm for $2 \mathrm{~h}$. After centrifugation, the supernatant was collected and the excess citrate which was not loaded in C-GNPs was estimated using a citrate assay kit (Sigma-Aldrich) according to the manufacturer's protocol. Amount of citrate loaded in C-GNPs was calculated by subtracting the amount of unloaded citrate from the total amount of citrate used for the synthesis of C-GNPs.

Estimation of EGCG loading: Loading of EGCG in E-GNPs was quantified by UV-visible spectroscopy. After synthesis, E-GNPs were centrifuged at 10,000 rpm for $2 \mathrm{~h}$ and the supernatant was collected. The concentration of EGCG in the supernatant was quantified using UV-visible spectrophotometry, at $272 \mathrm{~nm}\left(\lambda_{\max }\right)$. Amount of EGCG loaded in E-GNPs was calculated by subtracting the amount of EGCG in supernatant from the total amount of EGCG used for the reaction.

Cell viability and synergy studies: The viability of human normal and cancerous cells after treatment with E-GNP, EGCG, C-GNP, or citrate was determined by performing WST-1 assay. In brief, $5 \times 10^{3}$ cells were seeded in 96-well plates, cultured overnight, and treated with various concentrations of C-GNP $(0-200 \mu \mathrm{g} / \mathrm{mL})$, E-GNP $(0-200 \mu \mathrm{g} / \mathrm{mL})$, citrate $(0-0.82 \mathrm{mM})$, or EGCG (0-31.8 $\mu \mathrm{M})$. Following $96 \mathrm{~h}$ of treatment, cells were subjected to WST-1 assay as described earlier [29]. Since we did not observe dramatic growth inhibition of cancer cells by EGCG and GNPs, we performed synergy calculations at $20 \%$ cell growth inhibition. The combination index (CI) was calculated using Equation (1) [30]: 


$$
\mathrm{CI}=\frac{(\mathrm{D})_{1}}{\left(\mathrm{D}_{20 \%}\right)_{1}}+\frac{(\mathrm{D})_{2}}{\left(\mathrm{D}_{20 \%}\right)_{2}}+\frac{(\mathrm{D})_{1} \times(\mathrm{D})_{2}}{\left(\mathrm{D}_{20 \%}\right)_{1} \times\left(\mathrm{D}_{20 \%}\right)_{2}},
$$

where $\left(D_{20}\right)_{1}$ and $\left(D_{20}\right)_{2}$ are the doses of free EGCG and C-GNP, respectively, inhibiting $20 \%$ cell growth, while (D) 1 is the dose of EGCG and (D) 2 is the dose of GNP in E-GNP nanoformulation that gives $20 \%$ inhibition of cell growth.

Cellular uptake studies: RWPE1, MCF-10A, PC3, and MDA-MB-231 cells $\left(2.5 \times 10^{5}\right.$ cells/well) treated with E-GNPs $(50 \mu \mathrm{g} / \mathrm{mL})$ or C-GNPs $(50 \mu \mathrm{g} / \mathrm{mL})$ were collected at various time intervals $(1,3,6,12$, and $24 \mathrm{~h}$ ), after washing two times with PBS. For atomic absorption spectroscopy (AAS) analysis, cells were lysed by sonication and the released nanoparticles were centrifuged, washed, diluted appropriately in $1 \% \mathrm{HNO}_{3}$, and subjected to AAS analysis with a graphite furnace atomic absorption spectrometer (Perkin-Elmer AAnalyst 800, Waltham, MA, USA) equipped with AS 800 autosampler. A linear calibration curve between 20 and $160 \mathrm{ppb}$ was made by analyzing the dilutions made from a $1000 \mathrm{ppm}$ stock $\mathrm{Au}$ standard (Inorganic Ventures, Christiansburg, VA, USA) with $1 \%$ trace metal grade $\mathrm{HNO}_{3}$ in DI water. All analytical samples were in the range of the calibration curve. A $6 \mu \mathrm{L}$ aliquot of a $0.075 \% \mathrm{Pd}$ and $0.05 \%$ $\mathrm{Mg}\left(\mathrm{NO}_{3}\right)_{2}$ matrix modifier (Alfa Aesar, Ward Hill, MA, USA) was added to all the samples and standards. Sample injection volume was $20 \mu \mathrm{L}$. The $242.8 \mathrm{~nm}$ line from an Au hollow-cathode lamp was used for excitation, with a lamp current of $10 \mathrm{~mA}$. The furnace temperature program was as follows: Drying at $110{ }^{\circ} \mathrm{C}$ for $30 \mathrm{~s}$, followed by drying at $130{ }^{\circ} \mathrm{C}$ for $30 \mathrm{~s}$, followed by ashing at $800{ }^{\circ} \mathrm{C}$ for $20 \mathrm{~s}$, followed by atomization at $1800^{\circ} \mathrm{C}$ for $5 \mathrm{~s}$. All samples were run in triplicate. For TEM analysis, the cells were collected after $24 \mathrm{~h}$ of E-GNP $(50 \mu \mathrm{g} / \mathrm{mL})$ or C-GNPs $(50 \mu \mathrm{g} / \mathrm{mL})$ treatment and washed two times with PBS. The cells were pelleted by centrifugation and fixed overnight in $3 \%$ glutaraldehyde. After osmium tetroxide fixation, ethanol dehydration, and infiltration with propylene oxide/EPON 812, the pellet was embedded in EPON 812. After embedding, thin sections were cut, mounted on copper TEM grids, and examined on Philips CM100 TEM (Eindhoven, Netherlands).

Laminin receptor blocking study: RWPE1, MCF-10A, PC3, and MDA-MB-231 cells $\left(2.5 \times 10^{5}\right.$ cells/well) were seeded in six-well plates and incubated with anti-laminin receptor antibody, MLuC5 $(5 \mu \mathrm{g} / \mathrm{mL})$ for $1 \mathrm{~h}$. Thereafter, cells were treated with E-GNPs $(50 \mu \mathrm{g} / \mathrm{mL})$ or C-GNPs $(50 \mu \mathrm{g} / \mathrm{mL})$ for $3 \mathrm{~h}$ and lysed by sonication. Released nanoparticles were centrifuged, washed, diluted in $1 \% \mathrm{HNO}_{3}$ and subjected to AAS analysis with a graphite furnace atomic absorption spectrometer to determine their concentration. The cells which were not pre-incubated with MLuC5 were used as controls.

In vitro drug release study: E-GNPs ( $10 \mathrm{~mL}$ of $1 \mathrm{mg} / \mathrm{mL}$ suspension) or equivalent amount of free EGCG $(1.59 \mathrm{mM} ; 10 \mathrm{~mL}$ ) was placed in a dialysis bag ( $3.5 \mathrm{kDa}$ molecular weight cutoff). The dialysis bags were suspended separately in $100 \mathrm{~mL}$ of phosphate buffered saline (PBS, $\mathrm{pH} 7.4$ ) with gentle stirring at 37 $\pm 0.5^{\circ} \mathrm{C}$. Samples of $1 \mathrm{~mL}$ were collected from the incubation medium at predetermined time intervals and the removed incubation medium was replaced with equal volume of fresh PBS to maintain sink condition. The collected samples were analyzed by spectrophotometry to quantify EGCG release behavior.

Measurement of apoptosis: PC3 and MDA-MB-231 cells $\left(2.5 \times 10^{5}\right.$ cells/well) were exposed to EGCG $(11.9 \mu \mathrm{M})$, C-GNP $(50 \mu \mathrm{g} / \mathrm{mL})$, or E-GNP $(50 \mu \mathrm{g} / \mathrm{mL})$ for $72 \mathrm{~h}$. After treatment, cells were stained with 7-amino-actinomycin (7-AAD) and PE Annexin V using the PE Annexin V apoptosis detection kit and analyzed by flow cytometry as per manufacturer's instructions.

Nuclear and cytoplasmic fractionation: The cytoplasmic and nuclear extracts were prepared using the nuclear extract kit (Active Motif, Carlsbad, CA, USA) as described previously [31].

Immunoblot analyses: Immunoblotting was performed as previously described [32]. Briefly, protein samples $(60 \mu \mathrm{g})$ were resolved on $10 \%$ polyacrylamide gels and transferred to PVDF membrane. The membrane was blocked with 5\% milk for $1 \mathrm{~h}$ and exposed to the specific primary antibodies and incubated overnight at $4{ }^{\circ} \mathrm{C}$. Next, following washing with TBST buffer ( 3 times), the membrane was incubated for $1 \mathrm{~h}$ with horseradish peroxidase-conjugated secondary antibody. Bands were visualized using ECL plus western blotting substrate kit (Thermo Scientific) with an LAS-3000 image analyzer (Fuji Photo Film Co., Tokyo, Japan). 
NF- $\kappa B$ transcriptional activity assay: PC3 and MDA-MB-231 $\left(2.5 \times 10^{5}\right)$ cells were grown overnight in a six-well plate and transiently transfected with $1 \mu \mathrm{g}$ of NF-kB-luciferase reporter construct (i.e., pGL4.32 [luc2P/NF-kB -RE/Hygro]) and $0.5 \mu \mathrm{g}$ of Renilla luciferase control reporter vector (pRL-TK). After $24 \mathrm{~h}$ of transfection, cells were treated with EGCG $(11.9 \mu \mathrm{M}), \mathrm{C}-\mathrm{GNP}(50 \mu \mathrm{g} / \mathrm{mL})$, or E-GNP $(50 \mu \mathrm{g} / \mathrm{mL})$ for $24 \mathrm{~h}$ and the cell lysates were collected in passive lysis buffer. Luciferase activity was measured using the Dual Luciferase Assay System (Promega, Madison, WI, USA) according to the manufacturer's protocol.

Statistical analysis: Wherever suitable, the experiments were performed three times, and data expressed as mean \pm SD. Wherever appropriate, the data were also subjected to unpaired two-tailed Student's $t$-test. A value of $p<0.05$ was considered statistically significant.

\section{Results}

\subsection{Synthesis and Characterization of C-GNPS and E-GNPS}

C-GNPs were synthesized by reducing $\mathrm{HAuCl}_{4} \cdot 3 \mathrm{H}_{2} \mathrm{O}$ with trisodium citrate (TSC) as reported earlier [21], with some modifications. On the other hand, E-GNPs were synthesized by reducing $\mathrm{HAuCl}_{4} \cdot 3 \mathrm{H}_{2} \mathrm{O}$ with EGCG, at room temperature. After synthesis, C-GNPs and E-GNPs were characterized by UV-visible absorption spectroscopy, TEM, and DLS. The UV-visible absorption spectra analysis showed that both the nanoparticles (C-GNPs and E-GNPs) had $\lambda_{\max }$ at $530 \mathrm{~nm}$ (Figure 1B,E), indicating that the nanoparticles were of similar size [33]. Further, TEM analysis showed that both the nanoparticles were spherical in shape and $\sim 25 \mathrm{~nm}$ in diameter (Figure 1A,D). DLS analysis demonstrated that C-GNPs and E-GNPs had a very low polydispersity index (PD index), which implies uniform size distribution (Figure 1C,F). Further, hydrodynamic diameters of C-GNPs and E-GNPs were 41.7 and $90.3 \mathrm{~nm}$, and their zeta potentials were -81.16 and $-72.57 \mathrm{mV}$, respectively. The amount of citrate or EGCG attached to the surface of C-GNPs and E-GNPS, respectively, was assessed indirectly by quantifying the unloaded citrate or EGCG after the synthesis and subtracting it from the total amount used for the reactions. We observed that $1.2 \mu \mathrm{g}$ of citrate and $2.35 \mu \mathrm{g}$ of EGCG were loaded per $1 \mathrm{mg}$ of C-GNPs and E-GNPs, respectively (supplementary materials, Figure S1). In addition, we found that E-GNPs were stable even after 6 months of storage at $4{ }^{\circ} \mathrm{C}$ (supplementary materials, Figure S2).

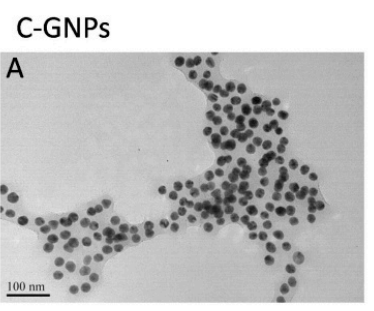

E-GNPS

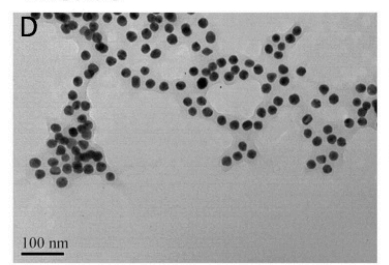

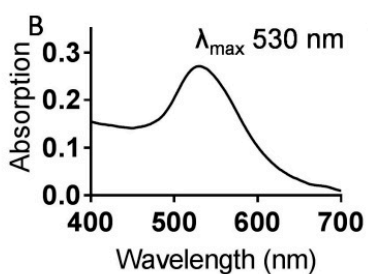

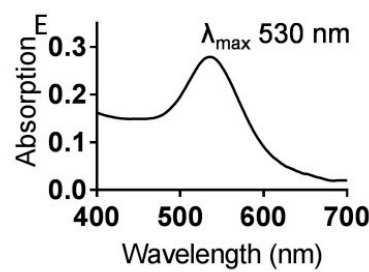

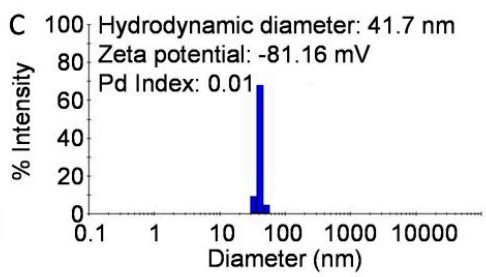

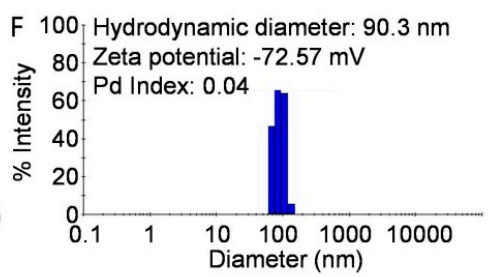

Figure 1. Characterization of citrate-gold nanoparticles (C-GNPs) and EGCG-gold nanoparticles (E-GNPs). (A) Transmission electron microscopy (TEM) image of C-GNPs shows that the nanoparticles are spherical in shape and $\sim 25 \mathrm{~nm}$ in size. (B) The absorption spectrum of C-GNPs showing $\lambda_{\max }$ at $530 \mathrm{~nm}$. (C) Dynamic light scattering (DLS) measurement of C-GNPs showing their size distribution, hydrodynamic diameter, and zeta potential. (D) TEM image of E-GNPs shows that the nanoparticles are spherical in shape and $\sim 25 \mathrm{~nm}$ in size. (E) The absorption spectrum of E-GNPs showing $\lambda_{\max }$ at $530 \mathrm{~nm}$. (F) Dynamic light scattering measurement of E-GNPs showing their size distribution, hydrodynamic diameter, and zeta potential. 


\subsection{E-GNPS Exhibit Selective and Superior Anticancer Activity}

Antitumor activity of E-GNPs, free EGCG, C-GNPs, and citrate was assessed on four human cancer cell lines (A375SM, MDA-MB-231, MIA PaCa, and PC3). As a control, we also used four non-cancerous (immortalized normal) cell lines (HaCaT, MCF10A, HPNE, and RWPE-1). Cells were treated with increasing concentrations of E-GNPs $(0-200 \mu \mathrm{g} / \mathrm{mL})$, EGCG $(0-31.8 \mu \mathrm{M})$, citrate $(0-0.82 \mathrm{mM})$, and C-GNPs $(0-200 \mu \mathrm{g} / \mathrm{mL})$ for $96 \mathrm{~h}$ and their viability measured by WST-1 assay. Our data demonstrated that E-GNPs caused significantly greater dose-dependent growth inhibition of cancer cells as compared to citrate, EGCG, or C-GNPs (Figure 2). IC 50 values of E-GNP were found to be 67.6, 54.7, 17.0, and $24.9 \mu \mathrm{g} / \mathrm{mL}$ for A375SM, MDA-MB-231, MIA PaCa and PC3, respectively. At comparable doses of C-GNPs and free EGCG, we observed growth inhibition of $4.3 \%$ and $3.8 \%$ (A375SM), 3.0\% and 5.8\% (MDA-MB-231), 4.9\% and 2.2\% (MIA PaCa), and 2.9\% and 4.0\% (PC3), respectively. Negligible or low toxicity towards normal cells was reported for free EGCG, citrate, and E-GNPs. In fact, at the highest dose (200 $\mu \mathrm{g} / \mathrm{mL})$, E-GNPs exhibited $19.0 \%, 16.9 \%, 1.4 \%$, and $18.5 \%$ growth inhibition for HaCaT, MCF10A, HPNE, and RWPE-1, respectively, as compared to 57.7\%, $45.8 \%, 41.6 \%$, and $48.8 \%$ for C-GNPs (Figure 2). Citrate exhibited negligible toxicity towards normal and cancer cells. The synergy calculations indicated synergism [combination index $(\mathrm{CI})<1$ ] between EGCG and GNPs in E-GNP nanoformulation with CIs of 0.19 (A375SM), 0.48 (MDA-MB-231), 0.12 (MIA PaCa), and 0.31 (PC3).


Figure 2. E-GNPs exhibit selective and superior anticancer activity. $5 \times 10^{3}$ noncancerous cells (HaCaT, MCF-10A, HPNE, and RWPE1) and cancerous cells (A375SM, MDA-MB-231, MIA PaCa, and PC3) were seeded in 96-well plates and treated with different concentrations of E-GNPs, epigallocatechin gallate (EGCG), C-GNPs, or citrate for $96 \mathrm{~h}$, and cell viability was determined by WST-1 assay. Data represent the mean of triplicates \pm SD. 


\subsection{Cancer Cells Internalize E-GNPs More Efficiently Than Normal Cells}

We analyzed the cellular uptake of C-GNPs and E-GNPs in normal (RWPE1 and MCF-10A) and cancerous (PC3 and MDA-MB-231) cell lines using TEM and AAS analysis after treating the cells with $50 \mu \mathrm{g} / \mathrm{mL}$ of C-GNPs or E-GNPs for $24 \mathrm{~h}$. TEM analysis revealed that there was no substantial difference in the uptake of C-GNPs between normal and cancerous cells, whereas E-GNPs were taken up by cancer cells more efficiently compared to normal cells (Figure 3A,B,E,F). Further, no nanoparticle clustering was observed in either of the nanoparticles even after cellular uptake (supplementary materials, Figure S3). Moreover, time-dependent uptake studies by AAS analysis indicated that C-GNPs were taken up slowly and less efficiently by all the cell lines (Figure 3C,D). Importantly, even after $24 \mathrm{~h}$ incubation, internalization of C-GNPs by different cell lines ranged only between $15.4-20.1 \%$. On the other hand, more than $50 \%$ of E-GNPs were taken up by both the cancer cell types within the first $3 \mathrm{~h}$ of incubation (Figure 3G,H). Furthermore, after $24 \mathrm{~h}$ of treatment, 69.3\% (PC3) and 70.9\% (MDA-MB-231) of E-GNPs were internalized (Figure 3G,H). Interestingly, internalization of E-GNPs was much less in both the normal cell lines [RWPE1 (6.6\%) and MCF-10A (7.0\%)] even after $24 \mathrm{~h}$ of incubation (Figure 3G,H). These results indicate that there is a $~ 10$-fold difference in the uptake of E-GNPs by normal and cancerous cells.
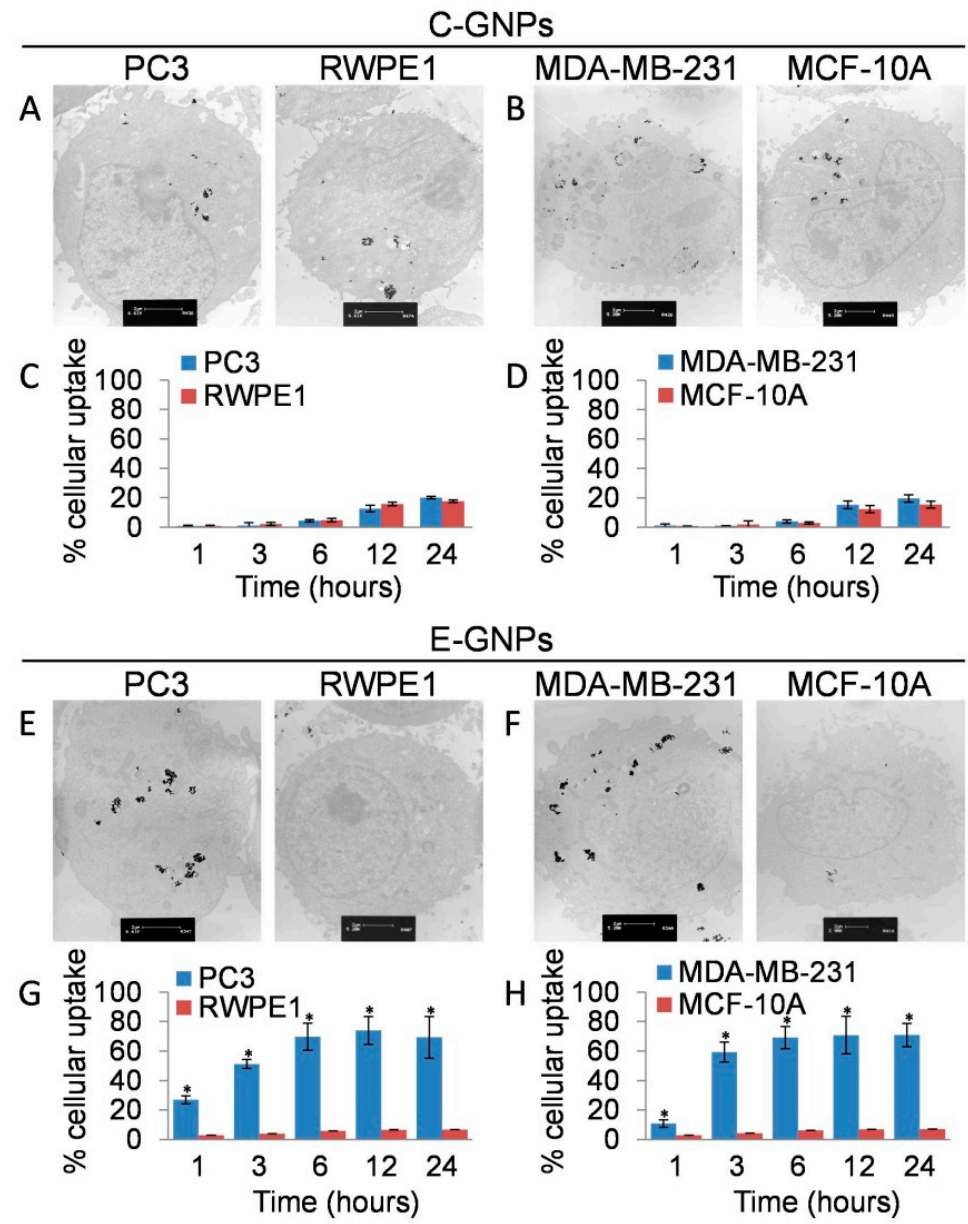

Figure 3. Cancer cells internalize E-GNPs more efficiently. TEM images of PC 3 and RWPE1 cells after $24 \mathrm{~h}$ treatment with C-GNPs (A) and E-GNPs (E) at $50 \mu \mathrm{g} / \mathrm{mL}$ concentration. TEM images of MDA-MB-231 and MCF-10A cells after $24 \mathrm{~h}$ treatment with C-GNPs (B) and E-GNPs (F) at $50 \mathrm{\mu g} / \mathrm{mL}$ concentration. Atomic absorption spectroscopy (AAS) analysis data from PC3 and RWPE1 cells show time-dependent cellular uptake of C-GNPs (C) and E-GNPs (G). AAS analysis data from MDA-MB-231 and MCF-10A cells shows time-dependent cellular uptake of C-GNPs (D) and E-GNPs $(\mathbf{H})$. Bars represent the mean of triplicates $\pm \mathrm{SD},{ }^{*} p<0.05$. 


\subsection{Laminin Receptor Blocking Reduces Uptake of E-GNPs by Cancer Cells}

EGCG is reported to serve as a ligand for the laminin receptor [12-15]. To determine if this was the cause of the efficient and selective uptake of E-GNPs by cancer cells, we first analyzed the expression of laminin receptors in cancerous and non-cancerous cell lines used in our study. We observed that all the cancer cell lines had significantly greater laminin receptor expression, as compared to non-cancerous cells (supplementary materials, Figure S4). Next, we performed a laminin receptor blocking experiment to determine their role in promoting uptake of E-GNPs by cancer cells. The data show that laminin receptor blocking by MLuC5 antibody led to a drastic decrease in cellular uptake of E-GNPs by cancer cells (PC3 and MDA-MB-231), whereas no significant difference was observed in the case of normal cells (RWPE1 and MCF-10A) (Figure 4A). Similarly, we did not observe any effect of laminin receptor blocking on cellular uptake of C-GNPs in all the cell lines tested (Figure 4B).

\section{C-GNPs}

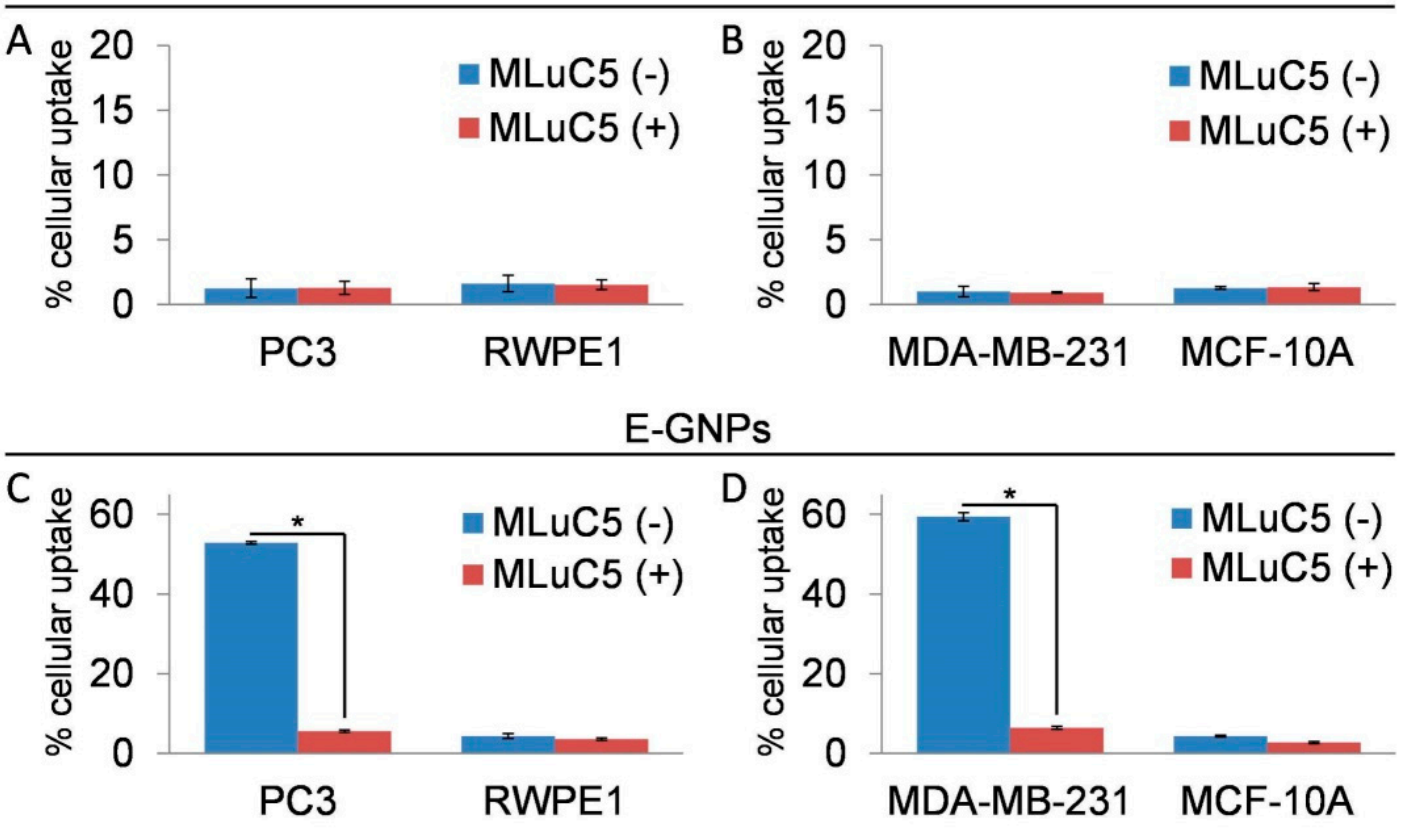

Figure 4. Laminin receptor blocking significantly reduces uptake of E-GNPs by cancer cells. Atomic absorption spectroscopy (AAS) analysis data from PC3 and RWPE1 cells showing the effect of laminin receptor blocking by MLuC5 antibody on cellular uptake of C-GNPs (A) and E-GNPs (C). AAS analysis data from MDA-MB-231 and MCF-10A cells showing the effect of laminin receptor blocking by MLuC5 antibody on cellular uptake of C-GNPs (B) and E-GNPs (D). Bars represent the mean of triplicates $\pm \mathrm{SD},{ }^{*} p<0.05$.

\subsection{E-GNP Nanoformulation Releases EGCG in a Sustained Fashion}

Slow and sustained release of a drug can lead to enhanced potency [34,35]. Therefore, we examined if the EGCG in E-GNPs nanoformulation was released slowly as compared to its free form in solution. EGCG release was monitored by dialysis, followed by quantification of released drug by spectrophotometry. We observed that $41.9 \%$ of the EGCG was released into the incubation medium from E-GNPs in $48 \mathrm{~h}$, and the sustained release continued for 5 days (Figure 5). In contrast, we observed that $85.9 \%$ of free EGCG was released from the dialysis bag into the incubation medium within $48 \mathrm{~h}$, and reached a plateau thereafter. These data suggest that E-GNP nanoformulation releases EGCG in a sustained fashion. 


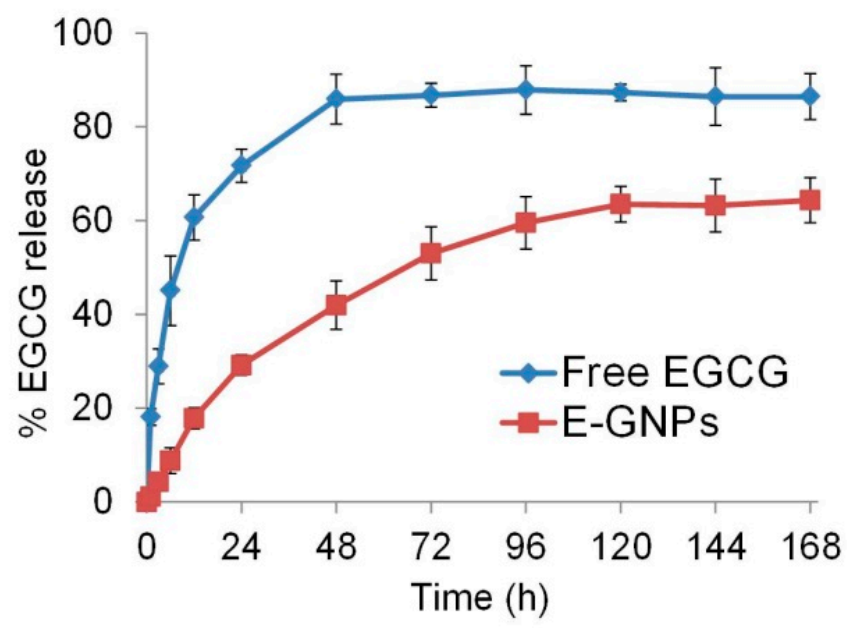

Figure 5. E-GNP nanoformulation releases EGCG in a sustained fashion. The time-dependent drug release behaviors of E-GNPs and free EGCG were quantified by spectrophotometry. The graph clearly shows sustained release of EGCG from E-GNPs nanoformulation. Data represent the mean of triplicates \pm SD.

\subsection{E-GNPs Induce Apoptosis in Cancer Cells More Potently Than C-GNPs}

To further explore the potential mechanisms by which E-GNPs induce growth inhibitory effects in cancer cells, we measured the extent of apoptosis after treatment with C-GNPs, E-GNPs, and free EGCG for $24 \mathrm{~h}$. Treated PC3 and MDA-MB-231 cells were stained with Annexin V and subjected to flow cytometry. We observed that EGCG induced 26\% (PC3) and 17.9\% (MDA-MB-231) apoptosis, whereas C-GNPs induced 24.7\% (PC3) and 17.6\% (MDA-MB-231) apoptosis (Figure 6A). Importantly, more apoptosis was observed in PC3 (48.0\%) and MDA-MB-231 (34.7\%) cells when they were treated with E-GNPs (Figure 6A). In addition, we also studied the expression of apoptosis-related proteins (BCL2, BCL-xL, Bax, cleaved caspase 7, and cleaved caspase 3), by immunoblotting, in PC3 and MDA-MB-231 cells treated with EGCG, E-GNPs, and C-GNPs for $24 \mathrm{~h}$. We observed a drastic reduction in the expression of anti-apoptotic proteins BCL2 and BCL-xL in E-GNPs treated cells as compared to those treated with EGCG and C-GNPs (Figure 6B). Similarly, treatment with E-GNPs resulted in the enhanced expression of Bax, cleaved caspase 7 and cleaved caspase 3 in both PC 3 and MDA-MB-231 cells in comparison to EGCG and C-GNPs (Figure 6B). 
A
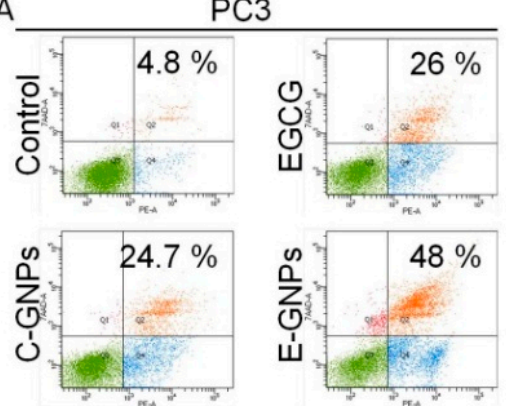

B

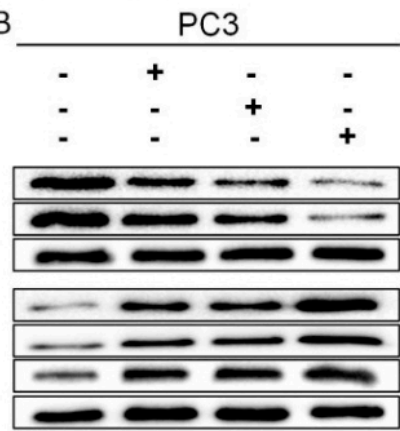

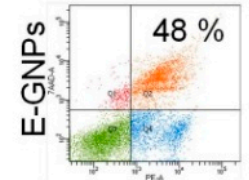

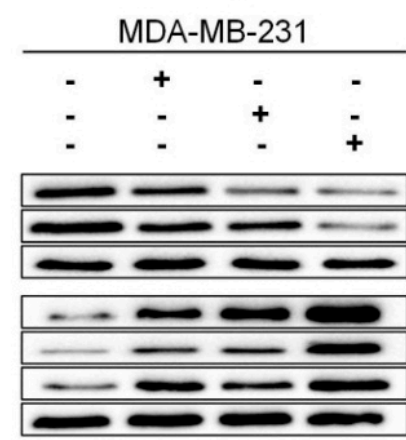

MDA-MB-231
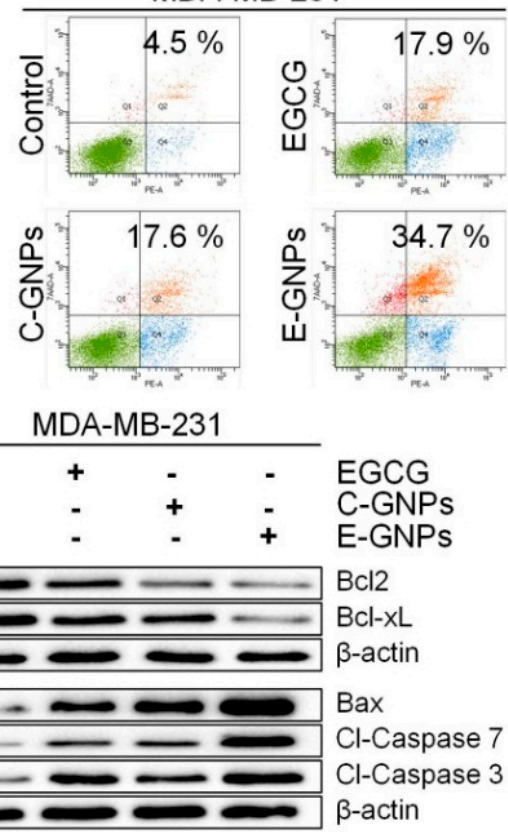

Figure 6. E-GNPs induce apoptosis in cancer cells. (A) The number of apoptotic cells after treatment with EGCG, C-GNPs, and E-GNPs was determined by Annexin V binding assay, using flow cytometry. (B) Total protein was isolated and immunoblot analysis was performed to analyze the expression of BCL2, BCL-xL, Bax, cleaved-caspase 7, and cleaved caspase 3. $\beta$-actin was used as loading control.

3.7. E-GNPs Abrogate Nuclear Translocation and Transcriptional Activity of NF- $\kappa B$ in Cancer Cells More Effectively Than Free EGCG or C-GNPS

NF- $\mathrm{KB}$ is known to regulate the expression of survival-associated genes, including those of members of the BCL2 family [31]. Moreover, EGCG has also been shown to reduce the activity of NF-kB [36]. Therefore, we sought to study and compare the effect of EGCG, C-GNP, and E-GNP on the activity of NF- $\mathrm{kB}$. Transcriptional activity of NF- $\mathrm{kB}$-responsive promoter-reporter was analyzed by dual-luciferase reporter assay in transfected PC3 and MDA-MB-231 cells treated with EGCG, C-GNP, or E-GNP (Figure 7A). In both the cell lines, E-GNPs caused excellent suppression of NF- $\mathrm{kB}$ transcriptional activity (65.5\% in PC3 and $73.7 \%$ in MDA-MB-231) as compared to free EGCG $(21.1 \%$ in PC3 and 31.3\% in MDA-MB-231) and C-GNPs (7.7\% in PC3 and 10.3\% in MDA-MB-231). The NF-kB dimers are present in the cytoplasm in an inactive form and upon activation, they translocate into the nucleus, where they bind to specific DNA motifs in the promoter/enhancer regions of target genes and activate their transcription [37]. To examine if these changes in NF- $\mathrm{kB}$ transcriptional activity resulted from altered sub-cellular localization, we isolated nuclear, cytoplasmic and total protein fractions from PC3 and MDA-MB-231 cells treated with EGCG, C-GNPs, or E-GNPs for $24 \mathrm{~h}$. Accumulation of $\mathrm{NF}-\mathrm{kB} / \mathrm{p} 65$ in the nucleus and cytoplasm or any changes in the overall expression was determined by immunoblot assay. Our data show that E-GNPs cause a significantly greater reduction in the nuclear accumulation of NF- $\mathrm{kB} / \mathrm{p} 65$ in cancer cells in comparison to EGCG and C-GNP (Figure 7B). No change in the level of total NF- $\mathrm{kB} / \mathrm{p} 65$ was detected after the treatment with EGCG, E-GNPs or C-GNPs (Figure 7B). 
A

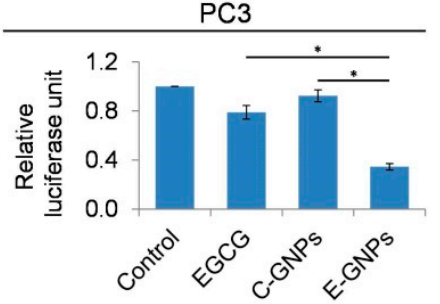

MDA-MB-231

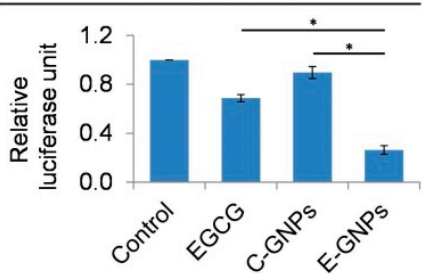

B

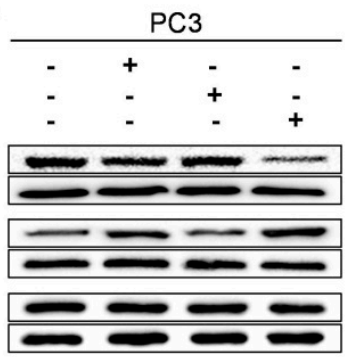

MDA-MB-231

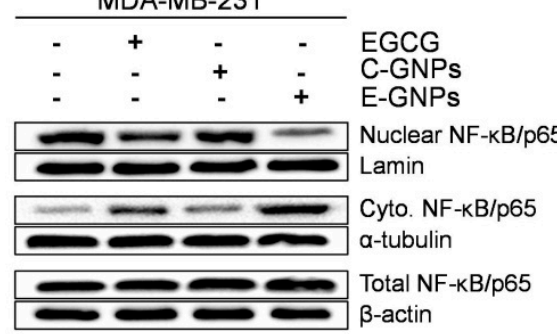

Figure 7. E-GNPs abrogate nuclear translocation and transcriptional activity of NF- $k B$ in cancer cells. (A) The NF-kB-luciferase reporter construct and Renilla luciferase control reporter vector transfected PC3 and MDA-MB-231 were treated with EGCG $(11.9 \mu \mathrm{M}), \mathrm{C}-\mathrm{GNP}(50 \mu \mathrm{g} / \mathrm{mL})$, or E-GNP $(50 \mu \mathrm{g} / \mathrm{mL})$ and NF-kB transcriptional activity was examined after $24 \mathrm{~h}$ using the Dual Luciferase Assay System. (B) After treatment with EGCG, C-GNPs, and E-GNPs, total protein was isolated and immunoblot analysis was performed to analyze the expression of nuclear NF- $\mathrm{B}$, cytosolic NF- $\mathrm{B}$, and total NF- $\mathrm{B}$. Lamin, $\alpha$-tubulin, and $\beta$-actin were used as loading controls respectively. Bars represent the mean of triplicates $\pm \mathrm{SD}, * p<0.05$.

\section{Discussion}

This study presents data to support the superior antitumor efficacy of EGCG-synthesized GNPs, as compared to conventional GNPs, due to potential synergistic interactions. EGCG, a bioactive polyphenol found in green tea [6], is shown to cause growth inhibition and apoptosis in several cancers $[8,9]$. However, its therapeutic applications are limited due to its poor stability and systemic bioavailability [16-18]. On the other hand, nanoparticles serve as drug carriers and provide protection to the loaded drugs [8,38]. More importantly, some nanoparticles, like GNPs, also possess intrinsic anticancer activity [23-27] and thus, combining the two may yield greater therapeutic benefit due to potential synergistic interactions.

We synthesized C-GNPs and E-GNPs by reducing Au(III) chloride with citrate and EGCG, respectively. Although our TEM data showed that both C-GNPs and E-GNPs had comparable shape and size distribution, the average hydrodynamic diameter of E-GNPs was higher than that of C-GNPs, possibly due to the difference in their surface coating. EGCG, upon reducing $\mathrm{Au}^{3+}$ to $\mathrm{Au}^{0}$, becomes physically adsorbed onto the GNP surface. Further, the high density of free-OH groups in EGCG could lead to the formation of a thick layer of EGCG supramolecular assemblies on the nanoparticle core, due to extensive inter- and intramolecular hydrogen bonding [39,40]. It is worth noting, however, that some amount of citrate/EGCG would have oxidized during GNP synthesis and indirect measurement of adsorbed citrate/EGCG may not provide us the precise estimate. Hence, in our comparison studies, we used the free citrate/EGCG amount that was comparable to the highest possible amount of unoxidized citrate/EGCG that could have been possibly adsorbed on the GNPs. Despite this, we observed that E-GNPs possessed superior anticancer activity in all the cancerous cell lines tested in comparison to free EGCG or C-GNPs. This increased anticancer activity of E-GNPs could be due to the increased stability of EGCG in the nanoformulation [41]. Furthermore, EGCG in E-GNP nanoformulation might have escaped efflux, as it is known that EGCG is actively pumped out of cancer cells in its free form [42,43] and nanoformulations of drugs can evade drug efflux [44-46]. Moreover, the superior anticancer activity of E-GNPs over C-GNPs could be due to the better cellular 
uptake of E-GNPs. All cancer cell lines used in our study exhibit an overexpression of laminin receptor. Since EGCG is shown to bind to laminin receptor [12-14], this might be an important mechanism for increased and selective cellular uptake of E-GNPs by cancer cells as compared to C-GNPs. To test this, we have done laminin receptor blocking studies and found that EGCG helps in cancer cell-specific uptake of E-GNPs by binding to overexpressed laminin receptors on these cells. As well as selective and increased uptake of E-GNPs by cancer cells, sustained release of EGCG from E-GNP nanoformulation could have resulted in this increased anticancer efficacy of E-GNPs. Additionally, the difference in hydrodynamic diameter of C-GNPs and E-GNPs might also have played a role in the differential uptake of the nanoparticles as reported by others in prior studies [47-49].

Apoptosis is a cellular suicide mechanism in which cells are programmed to die upon receiving an apoptotic stimulus to eliminate unwanted or unhealthy cells. However, cancer cells have developed mechanisms to resist apoptotic cell death through overexpressed of survival proteins. Considering the fact that both GNPs and EGCG induce apoptosis in cancer cells [26,50,51], we hypothesized that E-GNPs would exhibit superior efficacy. Our study revealed that exposure of PC3 and MDA-MB-231 cells to EGCG, C-GNPs, or E-GNPs induces apoptosis. However, E-GNP nanoformulation was the most efficient. This is likely due to synergistic interactions between EGCG and GNPs (i.e., EGCG stabilization by GNPs and increased uptake of E-GNPs facilitated by EGCG coating) as well as their inherent antitumor activities. We also found that anti-apoptotic proteins were downregulated and pro-apoptotic proteins were upregulated in all the three treatments, with treatment with E-GNPs showing a better outcome. A high Bax/Bcl-2 ratio can cause mitochondrial membrane depolarization, leading to the release of intermembrane space proteins into the cytosol, where they promote caspase-dependent apoptosis [52-54].

Several transcription factors, including NF- $\mathrm{kB}$, are suggested to regulate the expression of Bcl-2 and Bcl-xL in several cancer types [55]. Importantly, EGCG is reported to reduce the nuclear accumulation of NF- $\kappa B$ by downregulating IKK which activates NF- $\kappa B$ by phosphorylating I $\mathrm{B}$ [36]. NF- $k B$, a member of the Rel family of proteins, consists of closely related transcription factors that bind to the $\mathrm{kB}$ site, a common sequence motif in DNA $[36,56]$. NF- $\mathrm{kB}$ plays an important role in the regulation of multiple cellular processes including cell survival, proliferation, and apoptosis at the gene level [56]. The role of NF- $\mathrm{kB}$ in the pathobiology of several cancers has been explored well $[57,58]$. It has been established that cancer cells counteract the induction of apoptosis by the activation of NF- $\mathrm{KB}[59,60]$. The activated NF- $\mathrm{kB}$ is translocated from the cytoplasm to the nucleus, where it induces the expression of numerous genes involved in the suppression of apoptosis, including Bcl-2 and $\mathrm{Bcl}-\mathrm{xL}$ [55]. In this context, our data showing reduced nuclear accumulation and transcriptional activity of NF- $\mathrm{KB}$ is quite significant. Remarkably, the negative regulation of NF- $\mathrm{kB}$ by E-GNPs is significantly greater than that by free EGCG or C-GNPs. Further, C-GNPs did not show much effect on the NF-kB activity; however, the expression of apoptosis-associated proteins was regulated by C-GNPs. Notably, EGCG does have some repressive effect on NF-kB activity. We believe that the reason for synergism between EGCG and GNPs in E-GNPs is due to EGCG stabilization by GNPs and increased uptake of E-GNPs facilitated by EGCG through binding with laminin receptor. As well as increased stability and cellular uptake of E-GNPs, the simultaneous targeting of multiple signaling pathways involved in the activation of NF- $\mathrm{kB}$ by E-GNP nanoformulation could have caused this effect, which remains to be investigated in more precise detail in subsequent studies [61].

\section{Conclusions}

In conclusion, we report a synergistic anticancer activity between GNPs and EGCG in E-GNP nanoformulation. The increased cellular uptake or retention of E-GNPs and improved stability of EGCG in the nanoformulation might be the basis for this superior anticancer activity of E-GNPs. Overall, the data suggest that E-GNPs have great potential in the treatment of multiple types of cancer. A clear understanding of upstream and downstream events involved in the superior efficacy of E-GNPs is warranted to gain mechanistic insight and advance its potential for human applications. 
Supplementary Materials: The following are available online at http:/ /www.mdpi.com/2079-4991/9/3/396/s1. Figure S1: Quantification of EGCG loading on GNP; Figure S2: E-GNPs stability studies; Figure S3: Representative TEM images at high magnification $(28,500 \times)$; Figure S4: Laminin receptor expression in cancerous and noncancerous cell lines.

Author Contributions: Conception and design: S.S., A.P.S., S.R.C., S.K.D., R.K., N.T.; development of methodology: S.S., A.P.S., S.R.C., S.K.D., R.K., N.T., J.W.C.; experiment and data generation: S.R.C., S.K.D., R.K., N.T., J.W.C.; analysis and interpretation of data: S.S., A.P.S., S.R.C., S.K.D., R.K., N.T., J.W.C.; writing, review, and/or revision of manuscript of the manuscript: S.S., A.P.S., S.R.C., S.K.D., R.K., N.T., J.W.C.; study supervision: S.S., A.P.S. All authors read and approved the final manuscript.

Funding: This work was supported by the National Institute of Health/National Cancer Institute [CA204801 (to S.S.) and CA175772, CA185490 (to A.P.S.)] and USA Mitchell Cancer Institute.

Conflicts of Interest: The authors declare no conflict of interest. However, we would like to declare that A.P.S. and S.S. are co-founders and serve on the executive management team of Tatva Biosciences LLC, which is involved in the development of tools and models for biological research.

\section{References}

1. Siegel, R.L.; Miller, K.D.; Jemal, A. Cancer statistics, 2018. CA Cancer J. Clin. 2018, 68, 7-30. [CrossRef] [PubMed]

2. Tian, Y.; Guo, R.; Wang, Y.; Yang, W. Coordination-Induced Assembly of Intelligent Polysaccharide-Based Phototherapeutic Nanoparticles for Cancer Treatment. Adv. Healthc. Mater. 2016, 5, 3099-3104. [CrossRef] [PubMed]

3. Hubbell, J.A.; Chilkoti, A. Nanomaterials for Drug Delivery. Science 2012, 337, 303-305. [CrossRef] [PubMed]

4. González-Vallinas, M.; González-Castejón, M.; Rodríguez-Casado, A.; Ramírez de Molina, A. Dietary phytochemicals in cancer prevention and therapy: A complementary approach with promising perspectives. Nutr. Rev. 2013, 71, 585-599. [CrossRef] [PubMed]

5. Aqil, F.; Munagala, R.; Jeyabalan, J.; Vadhanam, M.V. Bioavailability of phytochemicals and its enhancement by drug delivery systems. Cancer Lett. 2013, 334, 133-141. [CrossRef] [PubMed]

6. Du, G.-J.; Zhang, Z.; Wen, X.-D.; Yu, C.; Calway, T.; Yuan, C.-S.; Wang, C.-Z. Epigallocatechin Gallate (EGCG) Is the Most Effective Cancer Chemopreventive Polyphenol in Green Tea. Nutrients 2012, 4, 1679-1691. [CrossRef]

7. Haque, S.A.; Cañete, S.J.P. HPLC-CUPRAC post-column derivatization method for the determination of antioxidants: A performance comparison between porous silica and core-shell column packing. J. Anal. Sci. Technol. 2018, 9, 4. [CrossRef]

8. Radhakrishnan, R.; Kulhari, H.; Pooja, D.; Gudem, S.; Bhargava, S.; Shukla, R.; Sistla, R. Encapsulation of biophenolic phytochemical EGCG within lipid nanoparticles enhances its stability and cytotoxicity against cancer. Chem. Phys. Lipids 2016, 198, 51-60. [CrossRef]

9. Zhang, J.; Lei, Z.; Huang, Z.; Zhang, X.; Zhou, Y.; Luo, Z.; Zeng, W.; Su, J.; Peng, C.; Chen, X. Epigallocatechin-3-gallate (EGCG) suppresses melanoma cell growth and metastasis by targeting TRAF6 activity. Oncotarget 2016, 7, 79557-79571. [CrossRef]

10. Bimonte, S.; Leongito, M.; Barbieri, A.; Del Vecchio, V.; Barbieri, M.; Albino, V.; Piccirillo, M.; Amore, A.; Di Giacomo, R.; Nasto, A.; et al. Inhibitory effect of (-)-epigallocatechin-3-gallate and bleomycin on human pancreatic cancer MiaPaCa-2 cell growth. Infect. Agent. Cancer 2015, 10, 22. [CrossRef]

11. Yang, C.S.; Wang, X.; Lu, G.; Picinich, S.C. Cancer prevention by tea: Animal studies, molecular mechanisms and human relevance. Nat. Rev. Cancer 2009, 9, 429-439. [CrossRef] [PubMed]

12. Kumazoe, M.; Tachibana, H. Anti-cancer effect of EGCG and its mechanisms. Funct. Foods Health Dis. 2016, $6,70-78$.

13. Zhou, Y.; Yu, Q.; Qin, X.; Bhavsar, D.; Yang, L.; Chen, Q.; Zheng, W.; Chen, L.; Liu, J. Improving the Anticancer Efficacy of Laminin Receptor-Specific Therapeutic Ruthenium Nanoparticles (RuBB-Loaded EGCG-RuNPs) via ROS-Dependent Apoptosis in SMMC-7721 Cells. ACS Appl. Mater. Interfaces 2016, 8, 15000-15012. [CrossRef] [PubMed]

14. Tachibana, H.; Koga, K.; Fujimura, Y.; Yamada, K. A receptor for green tea polyphenol EGCG. Nat. Struct. Mol. Biol. 2004, 11, 380. [CrossRef] [PubMed] 
15. Pesapane, A.; Ragno, P.; Selleri, C.; Montuori, N. Recent Advances in the Function of the 67 kDa Laminin Receptor and its Targeting for Personalized Therapy in Cancer. Curr. Pharm. Des. 2017, 23, 4745-4757. [PubMed]

16. Huo, C.; Wan, S.B.; Lam, W.H.; Li, L.; Wang, Z.; Landis-Piwowar, K.R.; Chen, D.; Dou, Q.P.; Chan, T.H. The challenge of developing green tea polyphenols as therapeutic agents. Inflammopharmacology 2008, 16, 248-252. [CrossRef] [PubMed]

17. Vaidyanathan, J.B.; Walle, T. Glucuronidation and Sulfation of the Tea Flavonoid (-)-Epicatechin by the Human and Rat Enzymes. Drug Metab. Dispos. 2002, 30, 897-903. [CrossRef] [PubMed]

18. Lu, H.; Meng, X.; Yang, C.S. Enzymology of Methylation of Tea Catechins and Inhibition of Catechol-O-methyltransferase by (-)-Epigallocatechin Gallate. Drug Metab. Dispos. 2003, 31, 572-579. [CrossRef] [PubMed]

19. Khan, A.K.; Rashid, R.; Murtaza, G.; Zahra, A. Gold Nanoparticles: Synthesis and Applications in Drug Delivery. Trop. J. Pharm. Res. 2014, 13, 1169-1177. [CrossRef]

20. Pramanik, A.; Chavva, S.R.; Viraka Nellore, B.P.; May, K.; Matthew, T.; Jones, S.; Vangara, A.; Ray, P.C. Development of a SERS Probe for Selective Detection of Healthy Prostate and Malignant Prostate Cancer Cells Using ZnII. Chem. Asian J. 2017, 12, 665-672. [CrossRef] [PubMed]

21. Chavva, S.R.; Viraka Nellore, B.P.; Pramanik, A.; Sinha, S.S.; Jones, S.; Ray, P.C. Designing a multicolor long range nanoscopic ruler for the imaging of heterogeneous tumor cells. Nanoscale 2016, 8, 13769-13780. [CrossRef] [PubMed]

22. Kong, F.-Y.; Zhang, J.-W.; Li, R.-F.; Wang, Z.-X.; Wang, W.-J.; Wang, W. Unique Roles of Gold Nanoparticles in Drug Delivery, Targeting and Imaging Applications. Molecules 2017, 22, 1445. [CrossRef] [PubMed]

23. Bhattacharya, R.; Mukherjee, P. Biological properties of "naked" metal nanoparticles. Adv. Drug Del. Rev. 2008, 60, 1289-1306. [CrossRef] [PubMed]

24. Melamed, J.R.; Riley, R.S.; Valcourt, D.M.; Day, E.S. Using Gold Nanoparticles to Disrupt the Tumor Microenvironment: An Emerging Therapeutic Strategy. ACS Nano 2016, 10, 10631-10635. [CrossRef] [PubMed]

25. Saha, S.; Xiong, X.; Chakraborty, P.K.; Shameer, K.; Arvizo, R.R.; Kudgus, R.A.; Dwivedi, S.K.D.; Hossen, M.N.; Gillies, E.M.; Robertson, J.D.; et al. Gold Nanoparticle Reprograms Pancreatic Tumor Microenvironment and Inhibits Tumor Growth. ACS Nano 2016, 10, 10636-10651. [CrossRef] [PubMed]

26. Selim, M.E.; Hendi, A.A. Gold Nanoparticles Induce Apoptosis in MCF-7 Human Breast Cancer Cells. Asian Pac. J. Cancer Prev. 2012, 13, 1617-1620. [CrossRef] [PubMed]

27. Patra, H.K.; Dasgupta, A.K.; Sarkar, S.; Biswas, I.; Chattopadhyay, A. Dual role of nanoparticles as drug carrier and drug. Cancer Nanotechnol. 2011, 2, 37-47. [CrossRef]

28. Sperling, R.A.; Rivera Gil, P.; Zhang, F.; Zanella, M.; Parak, W.J. Biological applications of gold nanoparticles. Chem. Soc. Rev. 2008, 37, 1896-1908. [CrossRef]

29. Deshmukh, S.K.; Srivastava, S.K.; Bhardwaj, A.; Singh, A.P.; Tyagi, N.; Marimuthu, S.; Dyess, D.L.; Zotto, V.D.; Carter, J.E.; Singh, S. Resistin and interleukin-6 exhibit racially-disparate expression in breast cancer patients, display molecular association and promote growth and aggressiveness of tumor cells through STAT3 activation. Oncotarget 2015, 6, 11231-11241. [CrossRef]

30. Wang, F.; Dai, W.; Wang, Y.; Shen, M.; Chen, K.; Cheng, P.; Zhang, Y.; Wang, C.; Li, J.; Zheng, Y.; et al. The Synergistic In Vitro and In Vivo Antitumor Effect of Combination Therapy with Salinomycin and 5-Fluorouracil against Hepatocellular Carcinoma. PLoS ONE 2014, 9, e97414. [CrossRef]

31. Tyagi, N.; Bhardwaj, A.; Singh, A.P.; McClellan, S.; Carter, J.E.; Singh, S. p-21 activated kinase 4 promotes proliferation and survival of pancreatic cancer cells through AKT- and ERK-dependent activation of NF- $\mathrm{KB}$ pathway. Oncotarget 2014, 5, 8778-8789. [CrossRef]

32. Deshmukh, S.K.; Tyagi, N.; Khan, M.A.; Srivastava, S.K.; Al-Ghadhban, A.; Dugger, K.; Carter, J.E.; Singh, S.; Singh, A.P. Gemcitabine treatment promotes immunosuppressive microenvironment in pancreatic tumors by supporting the infiltration, growth, and polarization of macrophages. Sci. Rep. 2018, 8, 12000. [CrossRef] [PubMed]

33. Haiss, W.; Thanh, N.T.K.; Aveyard, J.; Fernig, D.G. Determination of Size and Concentration of Gold Nanoparticles from UV-Vis Spectra. Anal. Chem. 2007, 79, 4215-4221. [CrossRef] [PubMed]

34. Singh, R.; Lillard Jr, J.W. Nanoparticle-based targeted drug delivery. Exp. Mol. Pathol. 2009, 86, $215-223$. [CrossRef] [PubMed] 
35. Panyam, J.; Labhasetwar, V. Biodegradable nanoparticles for drug and gene delivery to cells and tissue. Adv. Drug Del. Rev. 2003, 55, 329-347. [CrossRef]

36. Singh, B.N.; Shankar, S.; Srivastava, R.K. Green tea catechin, epigallocatechin-3-gallate (EGCG): Mechanisms, perspectives and clinical applications. Biochem. Pharmacol. 2011, 82, 1807-1821. [CrossRef] [PubMed]

37. Oeckinghaus, A.; Ghosh, S. The NF-кB Family of Transcription Factors and Its Regulation. Cold Spring Harb. Perspect. Biol. 2009, 1, a000034. [CrossRef]

38. Ghosh, P.; Han, G.; De, M.; Kim, C.K.; Rotello, V.M. Gold nanoparticles in delivery applications. Adv. Drug Del. Rev. 2008, 60, 1307-1315. [CrossRef]

39. Sanna, V.; Pala, N.; Dessì, G.; Manconi, P.; Mariani, A.; Dedola, S.; Rassu, M.; Crosio, C.; Iaccarino, C.; Sechi, M. Single-step green synthesis and characterization of gold-conjugated polyphenol nanoparticles with antioxidant and biological activities. Int. J. Nanomed. 2014, 9, 4935-4951.

40. Fissan, H.; Ristig, S.; Kaminski, H.; Asbach, C.; Epple, M. Comparison of different characterization methods for nanoparticle dispersions before and after aerosolization. Anal. Methods 2014, 6, 7324-7334. [CrossRef]

41. Granja, A.; Frias, I.; Neves, A.R.; Pinheiro, M.; Reis, S. Therapeutic Potential of Epigallocatechin Gallate Nanodelivery Systems. BioMed. Res. Int. 2017, 2017, 15. [CrossRef] [PubMed]

42. Hong, J.; Lu, H.; Meng, X.; Ryu, J.-H.; Hara, Y.; Yang, C.S. Stability, Cellular Uptake, Biotransformation, and Efflux of Tea Polyphenol (-)-Epigallocatechin-3-Gallate in HT-29 Human Colon Adenocarcinoma Cells. Cancer Res. 2002, 62, 7241-7246. [PubMed]

43. Hong, J.; Lambert, J.D.; Lee, S.-H.; Sinko, P.J.; Yang, C.S. Involvement of multidrug resistance-associated proteins in regulating cellular levels of (-)-epigallocatechin-3-gallate and its methyl metabolites. Biochem. Biophys. Res. Commun. 2003, 310, 222-227. [CrossRef] [PubMed]

44. Li, F.; Zhou, X.; Zhou, H.; Jia, J.; Li, L.; Zhai, S.; Yan, B. Reducing Both Pgp Overexpression and Drug Efflux with Anti-Cancer Gold-Paclitaxel Nanoconjugates. PLoS ONE 2016, 11, e0160042. [CrossRef] [PubMed]

45. Xue, X.; Liang, X.-J. Overcoming drug efflux-based multidrug resistance in cancer with nanotechnology. Chin. J. Cancer 2012, 31, 100-109. [CrossRef] [PubMed]

46. Cavaco, M.C.; Pereira, C.; Kreutzer, B.; Gouveia, L.F.; Silva-Lima, B.; Brito, A.M.; Videira, M. Evading P-glycoprotein mediated-efflux chemoresistance using Solid Lipid Nanoparticles. Eur. J. Pharm. Biopharm. 2017, 110, 76-84. [CrossRef] [PubMed]

47. Fröhlich, E. The role of surface charge in cellular uptake and cytotoxicity of medical nanoparticles. Int. J. Nanomed. 2012, 7, 5577-5591. [CrossRef]

48. Rahmani, S.; Ashraf, S.; Hartmann, R.; Dishman, A.F.; Zyuzin, M.V.; Yu, C.K.J.; Parak, W.J.; Lahann, J. Engineering of nanoparticle size via electrohydrodynamic jetting. Bioeng. Transl. Med. 2016, 1, 82-93. [CrossRef]

49. Dong, C.; Irudayaraj, J. Hydrodynamic Size-Dependent Cellular Uptake of Aqueous QDs Probed by Fluorescence Correlation Spectroscopy. J. Phys. Chem. B 2012, 116, 12125-12132. [CrossRef]

50. Noël, C.; Simard, J.-C.; Girard, D. Gold nanoparticles induce apoptosis, endoplasmic reticulum stress events and cleavage of cytoskeletal proteins in human neutrophils. Toxicol. In Vitro 2016, 31, 12-22. [CrossRef]

51. Min, K.-j.; Kwon, T.K. Anticancer effects and molecular mechanisms of epigallocatechin-3-gallate. Integr Med. Res. 2014, 3, 16-24. [CrossRef] [PubMed]

52. Gao, Z.; Kang, X.; Hu, J.; Ju, Y.; Xu, C. Induction of apoptosis with mitochondrial membrane depolarization by a glycyrrhetinic acid derivative in human leukemia K562 cells. Cytotechnology 2012, 64, 421-428. [CrossRef] [PubMed]

53. Qiao, J.; Wu, Y.; Liu, Y.; Li, X.; Wu, X.; Liu, N.; Zhu, F.; Qi, K.; Cheng, H.; Li, D.; et al. Busulfan Triggers Intrinsic Mitochondrial-Dependent Platelet Apoptosis Independent of Platelet Activation. Biol. Blood Marrow Transplant. 2016, 22, 1565-1572. [CrossRef] [PubMed]

54. Naseri, M.H.; Mahdavi, M.; Davoodi, J.; Tackallou, S.H.; Goudarzvand, M.; Neishabouri, S.H. Up regulation of Bax and down regulation of $\mathrm{Bcl} 2$ during 3-NC mediated apoptosis in human cancer cells. Cancer Cell Int. 2015, 15, 55. [CrossRef] [PubMed]

55. Aggarwal, B.B.; Shishodia, S. Molecular targets of dietary agents for prevention and therapy of cancer. Biochem. Pharmacol. 2006, 71, 1397-1421. [CrossRef] [PubMed]

56. Gupta, S.; Hastak, K.; Afaq, F.; Ahmad, N.; Mukhtar, H. Essential role of caspases in epigallocatechin-3-gallate-mediated inhibition of nuclear factor kappaB and induction of apoptosis. Oncogene 2004, 23, 2507. [CrossRef] [PubMed] 
57. Karin, M.; Cao, Y.; Greten, F.R.; Li, Z.-W. NF-кB in cancer: From innocent bystander to major culprit. Nat. Rev. Cancer 2002, 2, 301. [CrossRef]

58. Perkins, N.D. The diverse and complex roles of NF-kB subunits in cancer. Nat. Rev. Cancer 2012, $12,121$. [CrossRef]

59. Biswas, D.K.; Shi, Q.; Baily, S.; Strickland, I.; Ghosh, S.; Pardee, A.B.; Iglehart, J.D. NF-kB activation in human breast cancer specimens and its role in cell proliferation and apoptosis. Proc. Natl. Acad. Sci. USA 2004, 101, 10137-10142. [CrossRef]

60. Baichwal, V.R.; Baeuerle, P.A. Apoptosis: Activate NF-kB or die? Curr. Biol. 1997, 7, R94-R96. [CrossRef]

61. Fabre, C.; Mimura, N.; Bobb, K.; Kong, S.-Y.; Gorgun, G.; Cirstea, D.; Hu, Y.; Minami, J.; Ohguchi, H.; Zhang, J.; et al. Dual inhibition of canonical and non-canonical NF-kB pathways demonstrates significant anti-tumor activities in multiple myeloma. Clin. Cancer Res. 2012, 18, 4669-4681. [CrossRef] [PubMed]

C 2019 by the authors. Licensee MDPI, Basel, Switzerland. This article is an open access article distributed under the terms and conditions of the Creative Commons Attribution (CC BY) license (http://creativecommons.org/licenses/by/4.0/). 